\title{
Their Way or No Way: "Whiteness" as Agent for Marginalizing and Silencing Minority Voices In Academic Research and Publication
}

By

\author{
${ }^{1}$ Michael Baffoe, M.S.W, Ph.D, ${ }^{2}$ Lewis Asimeng-Boahene, M.A, Ph.D \\ ${ }^{3}$ Buster C. Ogbuagu, M.S.W, Ph.D
}

\begin{abstract}
The field of academic research and publication have traditionally been the almost exclusive domain of White Academics. They institute, control and apply "White codes" to syndicate the publication of academic journals, magazines and books, all from their White privileged positions in academia especially in the Western World. As a result of this, non-white academics especially those from the so-called Third World have had a lot of difficulty moving ahead in the world of academic research and especially publication in the journals, magazines and books that are controlled exclusively by White academics. Knowledge, in this sense, is therefore constructed, reconstructed, distributed and reproduced by Whites who, more often than not, see no value in the knowledge base of academics and researchers from the so-called Third World. Using Critical Race Theory and Post-Colonial Theory as the anchors of analysis, this study takes an oppositional and deconstructive stand on the construction, reconstruction, distribution and reproduction of knowledge in research and academia. It examines the experiences of non-white academics in this domain by telling their own story, not the single story" that "Whiteness" often tells about them. It makes recommendations that aim to promote equity in the arena of current and future knowledge construction and reproduction in research and academia.
\end{abstract}

Key Words: academic research; knowledge construction, White privilege; critical race theory; post-colonial theory, non-white academics

\section{Introduction}

The undercurrents of the global academy are such that Western researchers and institutions have jurisdiction or control over the construction, reconstruction and dissemination of knowledge. However, there is a dearth in the literature on the role "whiteness" as a norm plays in maintaining the privileges of whites in academia while marginalizing non-whites and thus erecting barriers and obstacles on their journey to

Associate Professor, University of Manitoba, Winnipeg-MB, Canada.

2 Associate Professor, Penn State University-Harrisburg, Harrisburg, PA, USA.

${ }^{3}$ University of St. Francis, Joliet-Illinois, USA. 
advancement in academia. This article extends the applications of the construction and sociology of knowledge to interrogate a postmodern analysis of racial discrimination and marginalization of non-whites in Western academia. It examines the experiences and challenges that non-white academics face in terms of production and dissemination of their scholarships. We begin by discussing the theoretical undercurrents that anchor the paper. Secondly, an overview of the concept of "Whiteness" is undertaken. Secondly, we undertake an overview of the concept of "Whiteness." We also foray into the discussion of the current global academy and politics of mainstream publication. It is followed by a discussion of the current global academy and politics of mainstream publication. We also examine the changing trends in knowledge production (research) and publication (globalization and scholarship). The changing trends in knowledge production (research) and publication (globalization \& scholarship) is also examined. We provide a prominent space for the narratives of some non-White scholars in the field of publication. Finally, we recommend, among others, the creation of future fora that would provide for the acceptance and dissemination of the knowledge construction of non-Western, non-white scholars in the global academic conversation.

\section{The concept and "Lens" of "Whiteness"}

In this section we identify some essential elements that constitute the 'lens' of whiteness, by drawing on some common understandings in the literature and presenting the findings of various researches that has have explored the concept. While this article is not aimed at providing a complete review of the concept "whiteness," it does provide a background against which we can start thinking differently about racism, race relations, and anti- racism which take have their anchors and strength from the continuous projection of "whiteness" as the norm in Western societies. These different ways of thinking include, but not limited to, interrogating power and privilege in the analysis of racism, which in turn may lead to more effective and critical action to address racism (Sefa-Dei, 1996). Although whiteness is a form of hegemony, its source of power is not monolithic, complete, or uniform (Frankenberg, 1997; Kincheloe \& Steinberg, 1998).

Whiteness is multifaceted, situationally specific, and re-inscribed around changing meanings of race in society.

"Whiteness" according to Guess (2006) consists of a body of knowledge, ideologies, norms, and particular practices that have been constructed over the history of Northern Europeans, and as such has roots in European history, during colonialism, as well as the establishment of the American colonies and the United States. Foucault (1972) is also of the opinion that race, but especially "whiteness" provides an archeology of knowledge for revealing the means in which symbolic concepts, which are based on race and whiteness foster intergenerational definition, self-reproduction and legitimation. The meaning of whiteness varies in relation to context, history, gender, class, sexuality, region, and political philosophy (Rasmussen, Klinenberg, Nexica, \& Wray, 2004; Gallagher, 2000; Shome, 1999; Kincheloe \& Steinberg, 1998; Frankenberg, 1997).

Contrary to commonsense and biological explanations, whiteness is understood in this article as a socially and politically constructed phenomenon subject to a multitude of influences. As well as providing a broad overview of whiteness, our aim is to highlight 
and establish dialogue about how research on whiteness may contribute to decolonization and work towards social justice.

Guess (2006) uses the example of the Jim Crow segregation laws to show how rudiments of socially constructed knowledge about race and whiteness have been recorded. Jim Crow segregation laws successfully, but un-meritoriously ascribed some measure of social devaluation of non-white peoples using the normative of racial characteristics. In this dispensation, continues Guess (2006), many non-white Americans, Blacks amongst them, have by intent been negatively impacted by racism, mainly that constructed by "Whiteness." "Racism by intent" (p.3), operating at the individual level manifests as racial prejudice, leading to discrimination and the ensuing consequences against individuals who are non-white.

Europe was already a white man's country at the time of the creation of North America. The imperialists of the new North America, United States and Canada, needed to institute measures to protect the white character of the emerging continent and countries. Hacker (1992) argues:

America is inherently a "white" country: in character, in structure, in culture. Needless to say, black Americans create lives of their own. Yet as a people, they face boundaries and constrictions set by the white majority. America's version of apartheid, while lacking overt legal sanction, comes closest to the system even now ... reformed in the land of its invention (p.4).

Whiteness as a socially constructed entity embeds racism in the interactional process, crystallizing and reproducing itself within the society where it operates. Racism as embodied in whiteness is hegemonious in that it permeates both current and past "fabrics" of powerful societies, especially in America where it is designed to remain invisible, inevitable and invincible (Ogbuagu, 2013). Having been this genetically modified, whiteness renders itself challenging to recognize, discuss and to deconstruct. Collins (2000) could not agree more and added that:

To maintain their power, dominant groups create and maintain a popular system of "commonsense" ideas that support their right to rule. In the United States, hegemonic ideologies concerning race, class, gender, sexuality, and nation are often so pervasive that it is difficult to conceptualize alternatives to them (p.284).

For Feagin (2000), racism in its daily routine acquires structural properties, which allows it to normalize and often rationalize racist attitudes and actions (see also Feagin, 2007; Feagin, Herman and Batur, 2001). Feagin (2000) posits that:

An ideology is a set of principles and views that embodies the basic interests of a particular social group. Typically, a broad ideology encompasses expressed attitudes and is constantly reflected in the talk and actions of everyday life. One need not know or accept the entire ideology for it to have an impact on thought or action (p.69).

The knowledge, ideologies, norms, and practices of "whiteness" affect how Europeans and White North American society think about race, what they see when they look at certain physical features, how "others" (other than "whites") build their own racial identities (Pascale, 2007), and what the "others" are made to "know" about their place in it (Shome, 1999). Whiteness is thus shaped and maintained by the full array of social institutions: legal, economic, political, educational, religious, and cultural (Rasmussen, 
Klinenberg, Nexica, \& Wray, 2004). Leonardo (2002) discusses the following as some of the defining characteristics of whiteness. Examples are:

- "An unwillingness to name the contours of racism" (p.32) in which situations like inequity in fields like employment, wealth and education is explained away by simple reference to other alternative factors "rather than being attributable to the actions of whites" (p.32).

- "Whiteness draws its power from 'othering' the very idea of ethnicity" (p.32), a process which assigns whiteness a process of 'naturalization' such that "white becomes the norm from which other 'races' stand apart and in relation to which they are defined" (Gillborn, 2005, p.489).

As a result of the competition now coming from the "others" impacted by "whiteness," "Whiteness" constantly seeks to reinvent (Warren and Twine, 1997) and protect its privileges, resources and opportunities (Steyn, 2001). Thus, whiteness is constantly evolving (Sullivan, 2006) in response to social forces and the constellation of people who are seen as white may change over time. According to Allen (1994), the knowledge, ideologies, norms, and practices of whiteness and the accompanying "white race" were invented in the U.S. as part of a system of racial oppression designed to solve a particular problem in colonial Virginia. Prior to that time, although Europeans recognized differences in the color of the human skin, they did not categorize themselves as white. We will provide more detail later.

For now, the important element of Allen's theorization is that whiteness serves to preserve the position of a ruling white elite who benefit economically from the labor of people of color. Whiteness, as knowledge, ideology, norms, and practices, determines who qualifies as "white" and maintains a race and class hierarchy in which the group of people who qualify as white disproportionately control power and resources (Wander, Martin \& Nakayama, 1999). Other writers postulate that within that group of white people, a small minority of elite control most of the group's power and resources. Not all studies of whiteness describe it as a system designed to economically benefit a small elite, but most agree that racial oppression is a key element in whiteness and that, as a group, white people do benefit disproportionally (Kincheloe, \& Steinberg, 1998).

\section{Whiteness as a Normalized Category}

Thompson (2001) posits that "Whiteness" theory treats whiteness not as a biological category but as a social construction. She points out that who counts as white depends on what is at stake. Critical Race Theory scholar Harris (2003) also suggests that whiteness should be best thought of as a form of property. Seen in this light, whiteness can be regarded as legal or cultural property which can be seen to provide material and symbolic privilege to whites, to those passing as white and in some situations to honorary whites. Typical examples of the material privileges accruing to whites and their surrogates would be better access to higher education, availability of choices of neighborhoods in which to live and those that should be stigmatized and the conceptions of beauty and intelligence which are tied not only to whiteness and its surrogates but excluding non-whites (Thompson, 2001). The above postulates therefore that white privilege and its survival depends on the devaluation of non-whites. 
Thompson (2001) divides whiteness theories into four major categories. These are: material theories which ask how whites as a group come to enjoy privileged access to tangible goods which include access to good education, health protection, legal protection, and basic civil liberties, which include the right and freedom to go anywhere without being followed or profiled. The next are discursive theories of whiteness which examine ways in which the mass media, language, symbols and discourses are structured with certain meanings in which whiteness gets framed as both the preferred and normative state of affairs. The third category involves institutional theories of whiteness which focus on how institutional regulations or codes privilege a certain discourse, a certain culture or value system. The fourth category which revolves around personal/relational theories looks at ways and mechanisms in which our relationships, our sense of decency and morality and sense of self are reconstructed and deconstructed all in enhancing the values implicit in white identity. These systems of privilege have clear material consequences because they operate within the institutional sub and superstructures including the organization of banks, schools, universities, policies, protocols and procedures. Our study therefore encompasses these categories of whiteness as espoused by Thompson (2001).

\section{Creating and maintaining whiteness through migration policies}

The following discussion of early immigration policy in Canada and the United States illustrates the intentional creation of "whiteness" is North America. Canada's immigration policy from its creation as a Confederation in 1867 up to the late 1960s was run under a mask of a strict "whites only" direction but in name. Canadian government policies since its Confederation were openly discriminatory towards people of color. Early immigrants that were encouraged to settle in Canada were from Northern Europe, notably from Britain, United States, Italy, Finland and the Ukraine.

The policies actively encouraged White immigrants to settle and farm in Canada (Bolaria $\& \mathrm{Li}, 1988)$. Canada openly discouraged the migration and settlement of people of color. For example, the first wave of Chinese labourers were recruited to work in the mines in British Columbia between 1850 and 1860 and the second wave of Chinese laborers were recruited to work on the Canadian Pacific Railway .

After the completion of the railway some Chinese male labourers (about 13,000) were recruited to fill the gap in labour supply in mining, fishing and sawmilling. These immigrants were not permitted to bring their wives and children or to have sexual relations with White women, for fear of spreading the "yellow menace" (Bolari \& Li, 1988).

In the same vein, the Chinese began to immigrate into the United States around 1849, and were immediately perceived by White Americans as a threat following the passage of the Naturalization Act of 1790, which explicitly declared and awarded citizenship to Whites only (Smith-Barusch, 2012). Undeterred, the Chinese in America continued to prosper, even in isolated and ghettoized China Towns, a situation that forced White labor organizations to successfully lobby for the enactment of the Chinese Exclusion Act of 1882. This Act banned the immigration of all Chinese to the United States, most of whom were just laborers (Smith-Barusch, 2012). 
In 1910 the Canadian government introduced another Immigration Act which, established a government policy of an excluded class of immigrants deemed "undesirable". This Act gave wide discretionary powers to Canadian immigration officials to exclude any prospective immigrant they deemed "undesirable" on the basis of race, national or ethnic origin and creed (Bolari \& Li, 1988). The "whites only", anticolor immigration policy of the Canadian government was underscored in a major policy speech in the House of Commons, the Canadian Legislature, in 1947 by then Prime Minister Mackenzie King. He stated inter alia:

The people of Canada do not wish, as a result of mass immigration, to make any fundamental alteration in the character of our population. Large-scale immigration from the Orient would change the fundamental composition of the Canadian population. Any considerable Oriental immigration would, moreover, be certain to give rise to social and economic problems of a character that might lead to serious difficulties in the field of international relations (Henry \& Tator, 2006, Malarek, 1987).

Black people did not fare any better on the preference list of the type of people Canada wanted to encourage to settle in the country. Canadian attitudes toward the immigration of Black people into Canada, was again underscored in an editorial in the Edmonton Capitol newspaper (in the Province of Alberta) in 1910, which summarized Canadian attitude towards Black immigration:

The Board of Trade has done well to call attention to the amount of negro immigration which is taking place into this district. It has already attained such proportion as to discourage White settlers from going into certain sections. The immigration department has no excuse for encouraging it all...We prefer to have the southern race problem left behind. The task of assimilating all the White people who enter our borders is quite heavy enough one without the color proposition being added (Shepard, 1991).

Persons of South Asian origin did not fare any better on the preference list of immigrants to Canada. South Asian presence in Canada was viewed as a "Hindu invasion". Various articles appeared in British Columbian newspapers emphasizing the importance of maintaining Anglo-Saxon superiority of the population of Canada (Raj, 1980). For example, The Victoria Daily Colonist in the British Columbian capital of Victoria issued this editorial:

To prepare ourselves for the irrepressible conflict, Canada must remain a White Man's country. On this western frontier of the Empire will be the forefront of the coming struggle... Therefore we ought to maintain this country for the Anglo-Saxon and those races which are able to assimilate themselves to them. If this is done, we believe that history will repeat itself and the supremacy of our race will continue (Henry and Tator, 2006).

The overview of Canada's Immigration Policy since Confederation until 1967 therefore divided the world into two parts. These were: "Preferred Immigrants" (of British and European ancestry and White) and the rest of the world, composed of people of color based on the premise that they had genetic, cultural, and social traits that made them both inferior and inadaptable (Bolari and Li, 1988).

\section{Theoretical framework}

This study was anchored, and its findings were analyzed within the realms of Post-Colonial Theory (PCT) and Critical Race Theory (CRT). Ghandi (1968) sees post- 
colonial theory as a post-modern intellectual entity that is composed of reactions to, and analysis of the distressful cultural legacies and vestiges of colonialism. It is also referred to as the cultural, intellectual, political, and literary movement of the twentieth and twenty-first centuries that is characterized by the representation and analysis of the historical experiences and subjectivity of the victims, individuals and nations of colonial subjugation and domination (Browne, Smye, and Varcoe, 2005; Macey, 2000).

Furthermore, Macey (2000) takes the stand that post-colonialism represents an adverse reaction by its victims, in that this movement seeks to uncover the historical and diverse conditions of its fabrication and sequelae to those who are its recipients. Postcolonial theoretical perspectives can therefore have the capacity to contribute to the understanding of how events from the past (colonial era) shape the present context of issues and events that affect the former colonial subjects (Browne et al, 2005). Thus we subscribe to Baffoe's (2013) argument that decolonization should be seen as a solution that draws on events from pre, colonial and post-colonial times to address the challenges emanating from the legacies of colonialism, thus deconstructing the preponderating dominant discourses.

Another theoretical lens guiding this study is Critical Race Theory (CRT), especially its emancipatory tenet of counter-story telling (DeCuir \& Dixson, 2004, Delgado \& Stefansic, 2001). CRT was utilized as a theoretical anchor on account of its insistence on the recognition of the experiential knowledge of people of color and/or marginalized persons and their communities of origins in analyzing society (McDonald, 2003; Degaldo \& Stefancic, 2001; Degaldo, 1995). In effect, CRT gives hitherto silenced voice to marginalized peoples the opportunity to tell their own stories and experiences within a theoretical framework where the epicenter of analysis is the narrative. Grant \& Asimeng-Boahene (2006) also point out that CRT quests for the de-shackling of the narratives of the marginalized by eliciting their needs and culture to support the empowerment as the end sight.

From the foregoing, CRT and its emancipatory tenet of counter story-telling are most relevant to the ideas highlighted in this study because it acknowledges race as a significant factor in the deconstruction of inequity and the hegemonic knowledge that has been previously constructed, distributed and reproduced (Crenshaw, Gotunda, Peller \& Thomas, 1995). This claim is especially pertinent when reviewing the dearth of attention often given to the reduction of publication from non-Western scholars to the foot note in academia (Grant \& Asimeng-Boahene, 2006).

CRT also offers a useful theoretical and intellectual tool for "deconstruction, reconstruction, and construction: deconstruction of oppressive structures and discourses, reconstruction of human agency, and construction of equitable and socially just relations of power" (Ladson-Billings, 2004, p. 51) in regards-to dissemination of ideas from non mainstream scholars. Narrative, represented in this study by counter story-telling is an effective vehicle for disseminating new knowledge that interrogates dominant discourses. Narrative is also a way to understand the lived experience of the story-teller (Degado \& Stephancic, 2001, Delgado, 1989).

The study is also conceptually housed in the social justice paradigm since, as Brooks \& Thompson (2005) point out, social justice could be seen as a way of recognizing, appreciating diversity, promoting equity, advancing broad-mindedness, and encouraging 
voice and expression. As Crenshaw et al (1995) also succinctly point out, critical race theory has an activist aspect: the end goal is to bring change that will implement social justice. Thus, the use of the counter story-telling in this study can be seen as a means of elucidating the stories and experiences of its participants, which are often not told or regarded as of little or no importance by mainstream academia and their patrons in the publishing industry.

\section{Global academy \& disturbing trends in the politics of mainstream publication}

It is common knowledge that in the area of academic publishing non-white scholars have incessantly complained about the rejection of their manuscripts by Western white publishers. As Yankah (1999) succinctly puts it:

"in the area of publishing, African scholars have lamented the marginalization of their manuscripts by western publishers, who complain of "intrusive" African vocabularies in titles and text, intrusive because they are not mainstream languages. Such "intrusions," it is said, could pose problems for marketing and smooth reading in the Western world. Other times, manuscripts and contributions have been rejected for being rather "descriptive," "too data-oriented," "lacking theoretical grounding," or "not in tune with global jargon and metadiscourse" (p.13).

Yankah (1999) further posits that these suppositions catalogues very unsettling disturbing trends in the body politics of academia, which refers to the total domination and control of global academic discourse and publishing by Euro and Americo-centric standards, and "the subsumption of local intellectual paradigms under received Western hegemonies; the monopolistic control of the center of academic authority; and, subsequently, the marginalization of other intellectual and their local academic agendas" (p.13).

We are also very much concerned in this study with the way the distribution of knowledge is conducted by western academy and publishers. As Yankah (1999) profoundly laments, "the Western academy also controls the strategic outlets of knowledge dissemination" (p.13). It is now clear that dissemination of knowledge has become an almost exclusive preserve, prerogative and the sole agenda for cryptic discourse within western academia. The above therefore surmises that "Africa and its disciplines are exotic intrusions that are outside of global discourse and require segregation" (p.13). Yankah (1999) continues in his lamentations on the sins of western academia in knowledge construction and dissemination. He poignantly insists that "such editorial segregation implies, once again, the existence of sanctified epistemological paradigms with which data and scholarship from all corners of the universe should come to terms if they are to attain "mainstream" recognition" (p.13).

\section{Methodology}

Our aim is to qualitatively explore connections and disconnections between whiteness and non-white in academic research and publication. Creswell (2007) explained that "qualitative research begins with assumptions, a worldview, the possible use of a theoretical lens, and the study of research problems inquiring into the meaning 
individuals or groups ascribe to a social or human problem" (p.37). This qualitative study therefore sampled the experiences of a number of non-white academics in Canada and the United States.

A qualitative research approach was deemed appropriate for this study because it offers a window through which we might see and able to comment on significant social issues (Maxwell, 2005; Denzin and Lincoln, 2000). The context of whiteness within which this study falls, include pertinent questions about how the academic lives of the participants (of non-white racial backgrounds) are organized. It is also about the ways in which nonwhites make sense of their lived experiences, which in this case, exist in the whitedominated academic environment. Of relevance to this study is the fact that, it is through qualitative research that context and method are related. It helps in observing and specifying the unique and shared features of socially organized settings, as well as analyzing the narratives of marginalized minority groups in mainstream cultural environments (Maxwell, 2005).

\subsection{Sampling Participants}

To obtain a comprehensive insight into how whiteness has served as a powerful agent for marginalizing non-whites in academia, this study employed a purposive sampling strategy. According to Berg (2001), researchers use a purposive sampling strategy when they want to "use their special knowledge or expertise about some group to select subjects who represent this population" (p.32). Erlander, Harris, Skipper, and Allen (1993) posits that, "purposive and directed sampling through human instrumentation increases the range of data exposed and maximizes the researcher's ability to identify emerging themes that take account of contextual conditions and cultural norms" (p.82).

\subsection{Data collection and analysis}

Data for this study was collected through in-depth, semi-structured interviews utilized to understand the experiences of other people and the meaning they make of that (Seidman, 1991). First we brainstormed a list of subjects that fit our criteria of purposive sampling. These potential participants were then contacted by phone, email and personal contacts. Personal (face-to-face, Skype and telephone) interviews were conducted with the participants. A total of thirty non-white academics were selected from academic institutions in North America and Europe. Three of the participants were, as at the time of the study, pursuing doctoral studies and had some experiences on the issue under study. The rest of the participants have all been in academia between five and twenty years and the experiences and challenges they recount span over this twenty-year period as at the time of this study in 2012 and 2013.

Within the situated context of the study, we settled on the following overarching research questions. The questions centred around their hopes and aspirations in joining academia, specific issues and challenges they have faced in the field of research and publications, and their opinions on the challenges and experiences they have had in this field. 


\subsection{In their own words: Narrative on experiences of non-white scholars on research and publication}

In line with the theoretical framework of CRT and its tenet of counter storytelling, this study sought to give voice to its participants to tell their own stories within the challenging, often painful experiences they have encountered in academia in North America and Europe. In the end, it was to do justice to the participants' own stories and to capture the richness of their experiences. Some of their stories are captured in the following narratives. They are given pseudo-names to protect their identity in line with the promise of confidentiality offered to the study participants:

Participant Eric, Canada: (in academia for twelve years)

Western academia is stacked with a lot of contradictions which work against the advancement of minorities, especially people of colour. When you are hired, it gets drummed in your ears that the key to your advancement is research and publication, publish or perish, they say. Yet the institutions, I mean journals and publication houses which are run by mainstream people continuously reject every research article you submit with the excuse that they do not fit their publication focus. They want the research information to be within their frame of thought, and were intolerant of ethnic, especially African vocabularies, but this is not right. It is absolutely necessary for the reading public especially higher education students to hear, read and learn about other trains of thought that are not necessarily Eurocentered. In my first five years as a full-time academic, I produced ten manuscripts, none of which was accepted by the mainstream publication journals. It kind of stresses you out and has serious impact on your health and direction of work.

Participant Ambi, United States: (in academia for ten years)

I have come to believe, after ten difficult years in academia that the challenges which are arrayed against minority people are deliberately structured and maintained. Most of my friends and colleagues who are also of minority racial backgrounds have reported the same difficult experiences in research and publication. It seems to me that any area that you research on and generate information for publication that is outside the cultural back.ground and thinking of mainstream society is viewed either with suspicion or dismissed as unimportant. It took me close to seven years to figure out the trend. It was then that I started researching for publication houses and journals that focus on minority issues to send my works to. The previous seven years were spent, I would say marking time on the same spot, so to speak.

Participant Guelli, United States (in academia for eight years)

It seems to me, and I am really convinced that these journal publishing houses are operating a kind of closely-knit club whose entry is jealously guarded. The odds are stacked against new faculty members at the Assistant Professor level especially minorities. There is intense pressure to research and publish. You complete an article and the journals commit you to give an undertaking that your work is being submitted to them alone. Then you wait between six months and eighteen months only to receive a rejection from them. Sometimes the way the rejection letters are written make you feel so bad and wonder where else you can turn to. In the meantime you go to look for another journal to send your work to and you are subjected to the same long waiting period and eventual rejection letter. So after four years you will be at the same spot you started from: a lot of research materials and no publication. And you start panicking as the tenure clock keeps ticking closer. I have examined many articles that have been published by the same journals that rejected mine and I don't see their qualities any different from the ones I-submitted and which got rejected. I took time to examine the names of the authors of these articles and the greater majority are all western-sounding names. Does that tell a story or I am being paranoid?

Participant Naledi, United Kingdom (in academia for 15 years) 
Most of my manuscripts were rejected by so-called impact factor journals with excuses which include the following that they lack global jargon or global academic discourse, or contain too much ethnic vocabulary although they were accompanied by English translations. The question I kept asking was who decides and defines what is global jargon? Who owns this global jargon? It should be borne in mind that the issues that some of us research have local cosmology with global implications and significance

\subsection{Examples of constant rejection letters on manuscripts received by some participants from mainstream journals}

Dear Dr..... regret to inform you that our reviewers have now considered your paper but unfortunately feel that it is unsuitable for publication in... (name of journal withbeld). It seems to have too much reliance on local and ethnic context of the location where the research was done... We struggle to see its international relevance to ... (name withheld) (June 2009)

Two weeks after receiving the above rejection for his manuscript, the same Journal sent him the following request:

Dear Dr..... The above manuscript titled.......has been submitted to...... for review and potential publication. I would be pleased if you would kindly agree to act as a reviewer for this manuscript. Please let me know as soon as possible if you will be able to accept my invitation to review

Yes, he was not considered good enough to be published but considered good to review manuscripts. He indeed reviewed the manuscript and received the following from the Journal's editor:

Dear Dr...Thanks to you for reviewing the above manuscript entitled....... We greatly appreciate the voluntary contribution that each reviewer gives to the journal. We hope we may continue to seek your assistance with the refereeing process for ...... and hope also to receive your own research papers that are appropriate to our aims and scope

They may have forgotten that they had rejected one of his "own research papers" a few weeks earlier for its inappropriateness to the journal's scope. What a contradiction!

Another one:

Dear Dr....I am writing to inform you that your Manuscript titled ......has not been accepted for publication in International Journal of.....As much as we appreciate the submission of your work and the fact that it represents research that enlightens us about communication in Africa, we think that the article has limited capacity to be comprehended globally.

Another one: This was in response to her enquiry to the journal on the status of her Manuscript submission after nearly twelve months and two previous enquiries:

Dear Dr...Thank you for re-contacting us about your journal submission. I have now received the reports from the blinded reviewers and we think that although your study covered a very important area of sociological research enquiry, we cannot accept the manuscript for publication since it relies too much on issues more pertinent to Asia.

And in another case, eighteen months of post-submission:

Dear Dr...... write to you in regards to manuscript \#.....entitled.....which you submitted to the International Journal of....... The chief editor has given your manuscript a careful reading. While finding it very well written, he finds it to be more a topic for anthropology than a social work. journal. Your subject matter is of great interest especially for those Africans who live in the diaspora. Unfortunately, it is not suitable for this journal. We hope the manuscript will receive a positive reception in another journal.

Ironically the area of study that this manuscript covered which is bereavement by people 
in the diaspora is a very relevant issue having social work implications, and the journal rejecting was a social work journal. If the issue of bereavement is not relevant to social work, we wonder what else is that may be "suitable" for a study or have social work relevance. In the white man's world, is African bereavement in the diaspora not of social work relevance, especially when these Diasporans live and work in the white man's world, where the outcomes of their grief may become manifest?

Another one (9 months after submission of manuscript)

I write to you in regards to manuscript \# 11-0032 entitled "... which you submitted to Journal of ... In view of the comments about your article by the reviewers and my own evaluation, I regret that I am not able to publish your article in the Journal of ... (name withheld). We receive_a large number of manuscripts for consideration and we can only publish a modest proportion of those submitted. Thank you for considering Journal of ......... for the publication of your research. I hope the outcome of this specific submission will not discourage you from the submission of future manuscripts.

Another one (after 14 months post submission of manuscript)

Dear...

Thank you for submitting your paper to the Journal of ...(name withheld). entitled...name withheld), (Manuscript ID 3020-10-0627). Regrettably I have to tell you that we have decided not to proceed with refereeing your paper, for the following reasons. The paper contains fascinating research material that are of interest to this journal, but we cannot accept it for publication at this time. Given the intrinsic interest of your material and its relevance to new immigrant communities, may I wish you success in placing your paper in another journal.

The pattern now seems clear: Although these responses are from different publishing houses and, we must add, different continents (North America and Europe), the wording and pattern of the rejection letters and delay (waiting) times are strikingly similar. Is there any co-incidence? We pause for an answer.

The journals and the publishers exhibit this audacity since they consider it a favor to the faculty for appointing them as reviewers, knowing that universities and educational institutions apply this as a stringent, indeed ruthless Tenure parameter. When one comes to think of it, it is only in academia that this "heist" is possible, operates and is perpetuated. Otherwise, tell me, if it is possible that one can go for consultations with a medical doctor, psychiatrist or a lawyer and after the consult, just walk out without paying them for the consult and other fees appertaining thereto. On the contrary, this is how journals and for-profit publishers use faculty to rake in billions of dollars each year, while the goose that lays the golden egg receives pittance by way of salary and emolument.

\section{Recommendations}

This study is not calling for a blanket acceptance and raw consumption of any research material. On the contrary, we are in quest for the creation of an active listening space and a level playing field for the voices of scholars and academics not originally from the western world. We therefore offer the following recommendations: 
We are proposing and calling for a new world academic order, which encompasses the voices, views, opinions, the cosmology, and the lived experiences of academics from all corners of the globe and from persons (and for our purpose) academics of all racial backgrounds. We should be mindful of an African proverb, "knowledge is like a baobab tree; no single person can embrace it."

It is pertinent to note the direct correlation between the difficulty that non-white academics encounter in the research and publication arena and their exclusion in recruitment, retention and promotion as faculty in higher educational institutions. Yale Daily News (2013) argued that Yale University must consciously and sincerely eradicate not only the entrance barriers facing women and minority faculty from being recruited into Yale. This is in consonance with what Myers (2005) opines, that there is the need to lift the obstacles that are intentionally put up to stifle the progress and eventual tenure of minorities which include research and publication challenges. This is further explicated by Cargill (2009) who expresses frustration over how minority professors are treated in universities. She posited that:

We in academic institutions are the bearers of the torch of knowledge, and have a unique responsibility to ensure that it is passed on to all without regard to race, color, creed, nationality, or sexual orientation. The true democratization of education, and the benefits it brings, will only occur when those who are underrepresented can be recruited, retained, mentored, and developed into a senior regiment ready to develop the next wave of scholars-through educating, modeling, and mentoring. We in academia need to look to ourselves to increase the number of the underrepresented in our ranks, incorporate more junior investigators into our projects, and push-repeatedly, vocally, and unwaveringly—-for a greater share of the funding pie for them (para.7).

\section{Open-access publishing}

Recognizing the fact that some of the major obstacles to research and publications hinge on the monopoly of journals and publishing conglomerates, we call for these monopolies to be broken with the institution of open-access publishing. In this arrangement, academic institutions pay for publication of their researchers' papers at input, and papers are then made available online. Warran (2003) supplied the example of BioMed Central, an independent publishing house which commitment to scientific publication has its ethos on open access to scientific materials being cardinal to the acceleration of scientific progress. Here, original research articles published by BioMed Central are made available and maintained online without cost to users, with peerreviewed and archived articles remaining the property of the author or authors. Revenue for maintaining the domain and achieved materials are generated through a nominal fee paid by authors whose articles have been accepted for publication. In summary, Kranich (1999) stated:

Increasingly, librarians and others in the academic community have concluded that they can no longer sustain a system in which their own faculty sign away the rights to their scholarship to commercial publishers that sell this content back at astronomical prices to a nearly captive market (para.9). 
It is ironic that the shylock publishing conglomerates have now instituted what is known as the "impact factor" which is the Ivy League of large publishing houses without whose recognition and pontifical blessing new authors especially cannot have sound academic recognition. However we believe that the so-called "impact factor" is only a new "firewall" [emphasis added] and post-modern exclusion paradigm, indeed subterfuge that these publishing western conglomerates are instituting in the face of the emerging competition from publishing houses in non-western countries. We therefore indignantly call for the abrogation of this so-called impact factor paradigm because it is ab initio a farce. We know that although open-access materials are increasingly becoming available, a large collection of the ones you must have for your research and publications are still under lock and key, and only accessible when you pay through your nose for them. Monbiot (2011) stressed, "You can start reading open-access journals, but you can't stop reading the closed ones" (para.12). Be this as it may, open-access publishing heralds the genesis of the deconstruction of the ghoulish properties of the publication conglomerates. That is why the argument for the abrogation of the impact factor paradigm is unimpeachable, of uttermost importance and urgent

\section{Modification of the premium of research and publications as pre-requisite for Tenure and Promotion}

Using publications, the number of publications, the prestige of the journals and other categories to assess a faculty for the granting of tenure and promotion has existed as a Eurocentric construct for several hundred years. It is time to re-evaluate this practice because we now live in a global world which is not only characterized by the paradigms of Eurocentrism and Americentrism, but by other equally important "centrisms" (emphasis added). Moreover, the utilization of this process to evaluate faculty for tenure is as oppressive as the denial of Civil Rights because it is not a level-playing field. Those faculty, who are "well-connected" (emphasis added) in the journal publication and research "syndicate" (emphasis added) fare well, while those who are not "networked," (emphasis added) represented by a large number of minorities have no cultural base in the Euro-centered "world" to gain a foothold. The "syndicate" is in-breeding and continues to use "double-blinded" review process to include and sustain themselves, while they use the same mechanism to exclude others, who are different or presumed to be different.

The fact of the matter is that using publications and the number of publications that a new faculty has, and this is where a large number of minorities as Assistant Professors are (Yale Daily News) gives too much power and control to the journals, the for-profit publishers and other cronies in the syndicate. It also wrests intellectual property rights from the new faculty, who must sign over their hard work to these post-modern "mafia" who then sells them back at exorbitant rates to the same university libraries from whence the authors came in the first instance. Kranich (1999) puts it aptly:

Scholarly communication is a complex process that requires faculty to publish in order to be tenured or promoted. The current publishing environment is a monopoly-like marketplace increasingly dominated by large commercial conglomerates. In order to 
transform the process, the higher education community must take collective action (para.16).

What might this collective action that Kranich (1999) argued about be? It may begin with higher institutions from the so-called Third World countries finding the necessary resources to publish and archive their own materials. This argument finds support from many academics, including Monbiot (2011), an English writer and political activist who argues for a single global archive of data and academic literature, overseen by an independent and genuine body of Peer-Reviewers. This paradigm also proposes that the archive and its maintenance be sustained from existing library budgets, which as property are currently being appropriated by for-profit conglomerates.

The current trend which has existed for many decades will continue, even find new dimensions to further emasculate faculty if something does not occur soon to stop it. In this dispensation, the "fall guys" [emphasis added] are again Assistant Professors, and most Assistant Professors (Yale Daily News, 2013; Cargill, 2009) are minorities, perceived as the Marxian dregs of the academic discipline, who have been used to saturate the lower faculty hierarchy, in addition to being the ones that are let go when they are seen as not publishing or publishing enough.

\section{Conclusion:}

What explanations can be offered for the continuous marginalization and all the obstacles and challenges that are thrown in the path of non-white academics in academia in the areas surveyed? Cote (2009) offers a succinct theory for this state of affairs. In an interesting article titled "Education and the Colonial Construction of Whiteness," Cote points out that education and the education field were first used by the colonialists in the colonial outposts in Asia and Africa to counter the growing vulnerability of whiteness either as a physical or cultural category for domination.

The university represents one of the areas in education, where Darwin's survival of the fittest axiom holds most true. It begins mostly with acquiring a terminal degree, usually a $\mathrm{Ph} . \mathrm{D}$. in itself a gargantuan task and a very lonely road for those who dared to follow it to its final destination. If on completion the hapless "doctor" thinks that their struggle is over, they need to rethink this assumption, for this is when the real struggle, a form of lemming rush actually begins. The pursuit of the almighty Tenure and subsequent promotion takes precedence over every other pursuit, in that it has the three components of teaching, scholarly activities and service, all of which have criteria that must be vigorously met to be considered for tenure. In mostly research institutions, as against teaching institutions, the securing of grants and other sources of funding will be inserted in the pouch of research and publication.

We suggested the deconstruction of the problematics of the artificial barriers created by this Whiteness in the erasure of the monopolistic-type "double-blinded review" that has a hidden agenda. This hidden agenda insures the pursuit of the extinction of minority academics, a condition that continues to allow whiteness to sustain its "single story" encapsulated in self-aggrandizement and simultaneous de-aggrandizement of those who are not white or who fail to see white story as "the story." 
We also suggested the enlargement and maintenance of the open-access system of research and journal publication in such ways that the power of the for-profit publishing conglomerates are circumvented or decreased. In the realm of the knower privilege, Whites routinely travel to Africa and other "Third World" nations to "study them" and return with blended and sometimes mutilated narratives, which immediately receive acclaim among their peers in the west. This is because those stories are exotic and esoteric and expose "primitive" lives that are worthy of study and understanding, in the end promoting the pioneering enterprise and spirit of the white "savior" here in the west. However, when scholars from these same regions want to tell their own story by themselves, in unblemished, unembellished, authentic and unadulterated forms, they are not acceptable to the same western evaluators who passed off the "single stories" that garnered acclaim from their cohort. Ironically these are the same stories and narratives that we bring to the mix, which are roundly, resoundly rejected and denigrated as subpar. This, in our opinion, amounts to epistemological ethnocentrism.

A recent article in the New York Times written by Gina Kolata (April, 7, 2013) splashed the following headline "Scientific Articles Accepted (Personal Checks, Too)." This article decried the ostensible proliferation of open-access scientific journals whose proprietors charge exorbitant publication fees but produce what it termed "pseudo-academia" material. However a careful examination of the article reveals the discomfort, uneasiness, even paranoia of the so-called impact factor publishing conglomerates. They condemned the emergence of these open-access journal publications and even went further to call for the "black-listing" of the open-access publications and the creation of a "white list" of those open-access journals that "meet certain standards." The very pertinent question that needs to be asked is "whose standards?" Is it a "standard" that meets the yardstick of their "white list" or the standards to which whites and non-whites should all be subjected to? Now "whiteness" is again trying to exert its power, influence, and suzerainty by attacking this phenomenon as a "rise of questionable operators."

This article in The New York Times sought to create a very false impression that the practice of charging authors for academic publication is unusual and limited to the socalled open-access upstart journals. Far from that: the majority of the so-called "respected" and high-impact factor journals have for a very long time charged authors exorbitant publication fees to publish, only to turn around and sell the same publication to the authors when they try to gain access to copies of their intellectual property. All the while they have reaped massive profits from this practice, and are now petrified of losing their stranglehold on authors. This is the bread and butter practice of publishing houses. We hasten to question the difference between the business practices of the open-access publications who charge publication fees upfront to their authors and the mainstream "closed access" publications who sell these articles to even their own fee-paying contributors/authors after publication? Again we pause here for an answer!

We can draw a parallel between these publication wars to the protracted debacles between the large western pharmaceutical companies and the smaller Asian ones over patent rights. The big pharmaceutical companies have been battling the smaller Asian pharmaceutical companies for patent rights to prevent the production of generic drugs, which tests have been shown to cure the same illnesses (Padma and Nature Magazine, 2013). In the same vein, we regard the emergence of these open-access, low publication 
cost journals as "generic" academic journals which are providing the same services and access to publications whose entry and access were hitherto closed to the "poor" nonwhite academics. Fair competition, or fair trade, isn't it?

As an epilogue we will leave our readers with the wisdom encapsulated in the African proverb which says that ti koro nko agyina, [oops! have we used the forbidden "intrusive" African vocabulary that is "not in tune with global jargon and metadiscourse?"] to wit, $a$ single head cannot exchange ideas. We need all heads, whites, honorary whites and non-whites to generate, and distribute the knowledge of this world. We recall the treasured advice of the revered Kwegyir Aggrey of Africa who poignantly put it, to play the white only or black keys only on the piano cannot generate harmony. You need a blend of white and black keys to generate harmonious and melodious music which will be soothing to all ears.

\section{References}

Allen, T. (1994). The Invention of the White Race (Part 1). New York: Verso

Baffoe, M. (2013). Spiritual Well-being and fulfilment, or exploitation by a few smart ones?

The proliferation of Christian Churches in West African Immigrant Communities in Canada. Mediterranean Journal of Social Sciences. Vol. 4(1) pp. 305-316.

Barusch-Smith, A. (2012). Foundations of Social Policy: Social Justice in Human Perspectives (4 $4^{\text {th }}$ Ed.). Brooks/Cole, Cengage Learning.

Berg, B. L. (2001). Qualitative research methods for the social science. Needham heights, MA: Allyn \& Bacon.

Bolari, S. B., and Li, P. S., (1988). Racial Oppression in Canada. Toronto: Garamond Press.

Browne, A. J., Smye, V. L., and Varcoe, C. (2005). The Relevance of Postcolonial Theoretical

Perspectives to Research in Aboriginal Health. Canadian Journal of Nursing Research, 37(4): 16-37.

Cargill, V. A. (2009, April). Recruiting, Retaining, and Maintaining Racial and Ethnic Minority Investigators: Why We Should Bother, Why We Should Care. Am J Public.

Crenshaw, K., Gotunda, N., Peller, G., \& Thomas k. (1995). Introduction. In K. Crenshaw, N.

Gotunda, G. Peller, \& K. Thomas (Eds.), Critical race theory: The key writings that formed the movement (pp. xiii-xxxii), New York, NY: The New Press.

Creswell, J. (2007). Qualitative inquiry and research design: choosing among five traditions. Thousand oaks, CA: Sage

Delgado, R. (1989). When a story is just a story: Does voice really matter? Virginia Law Review, 76, 95-111.

Delgado, R., \& Stefansic, J. (2001). Critical race theory: an introduction. New York: New York University Press.

Erlander, D. A., Harris, E. L., Skipper, B. L., \& Allen, S. D.(1993). Doing naturalistic inquiry: A guide to methods. Thousand Oaks, CA: Sage.

Feagan, J. R. (2007). Systemic Racism: A Theory of Oppression. Community Development Journal, Vol. 42, No. 1, pp. 134-145.

Feagin, J. R. (2000). Racist America: Root, Current Realities, and Future Reparations. New York: Routledge.

Feagin, J. R.; Vera, Herman; \& Pina, Batur. (2001). White racism: The Basics. New York \& London: Routledge.

Foucault, Michel (1972). Archeology of Knowledge. New York, NY: Pantheon Books.

Frankenberg, R. (1997). Introduction: Local whitenesses, localizing whiteness. In R. Frankenberg (Ed.), Displacing whiteness: Essays in social and cultural criticism (pp. 1-33). Durham, 
NC: Duke University Press.

Gallagher, C. A. (2000). White like me? Methods, meaning, and manipulation in the field of white studies. In F. W. Twine \& J. W. Warren (Eds.), Racing research, researching race: Methodological dilemmas in critical race studies (pp.67-92). New York: New York University Press.

Ghandi, L. (1968). Post-colonial Theory: A Critical introduction. New York: Columbia University Press

Gillborn, D. (2005). Education policy as an act of white supremacy: whiteness, critical race theory and education reform, Journal of Education Policy, 20(4), 485-505.

Guess, T. J. (2006). The Social Construction of Whiteness: Racism by Intent, Racism by Consequence. Critical Sociology, vol. 32(4).

Hacker, A. (2003). Two Nations: Black and White, Separate, Hostile, Unequal. Scribner;

Rep Sub edition.

Harris, C. I. (2003). Whiteness as property. In L.M. Alcoff \& E. Mendieta (Eds.), Identities: Race, class, gender \& nationality (pp.75-89). Malden, MA: Blackwell Publishing.

Hartigan, J. J. (1997). Locating white Detroit. In R. Frankenberg (Ed.), Displacing whiteness: Essays in social and cultural criticism (pp. 180-213). Durham, NC: Duke University Press.

Henry, F., and Tator, C. (2006). Racial Profiling in Canada: Challenging the Myth of 'A Few Bad Apples'. Toronto: University of Toronto Press.

Hytten, K., \& Warren, J. (2003). Engaging whiteness: How racial power gets reified in education. International Journal of Qualitative Studies in Education, 16(1), 65-89.

Kincheloe, J. L., \& Steinberg, S. R. (1998). Addressing the crisis of whiteness: Reconfiguring white identity in a pedagogy of whiteness. In J. L. Kincheloe, S. R. Steinberg, N. M. Rodriguez, \& R. E. Chennault (Eds.), White reign: Deploying whiteness in America (pp. 3-29). Basingstoke: Macmillan.

Kolat, G. (2013). Scientific Articles Accepted (Personal Checks Too). The New York Times. New York, April 7, 2013.

Kranich, N. (1999). Scholarly Publications Hold Universities Hostage: Monopoly on Journals Causes Prices to Soar. Retrieved May 18, 2013 from http://fair.org/extra-onlinearticles/scholarly-publications-hold-universities-hostage/

Ladson-Billings, G. (2004). Just what is critical race theory and what's it doing in a nice field like education? In G. Ladson-Billings \& D. Gillborn (Eds.). The Routledge Falmer Reader in multicultural education critical perspectives on race, racism and education. London: Routledge Farmer.

Levinson, M. (2002). Minority participation \& civic education in deliberative democracies. In Avner de-Shalit \& D. Bell (Eds.). Forms of justice. Boulder: Rowman \& Littlefield.

Macey, D. (2000). Dictionary of Critical Theory. London: Penguin Books.

Malarek, V. (1987). Heaven's Gate: Canada's Immigration Fiasco. Toronto: Macmillan

McDonald, H. (2003). Exploring Possibilities Through Critical Race Theory: Exemplary

Pedagogical Practices for Indigenous Students. Paper Prepared for NZARE/AARE. Australia: James Cook University.

Monbiot, George (2011, August, 29). Academic publishers make Murdoch look like a socialist.

The Guardian, UK. Retrieved April 27, 2013 from

http://www.guardian.co.uk/commentisfree/2011/aug/29/academic-publishersmurdoch-socialist

Myers, K. (2005). Racetalk: Racism Hiding in Plain Sight. Toronto: Rowman \& Littlefield Publishing Inc.

Naidoo, A. V. (1996). Challenging the hegemony of eurocentric psychology. Journal of 
Community Health Sciences, 2(2), 9-16.

Ogbuagu, B.C. (2013). Constructing America’s "New Blacks": Post 911 Policies

and their Impacts on and Implications for the Lived Experiences of Arabs, Muslims and "Others." Mediterranean Journal of Social Sciences Vol. 4 (1), pp.469-480, ISSN 2039-9340.

Padma, T.V., and Nature Magazine (2013, April 1). India Court Ruling Upholds Access to Cheaper, Generic Drugs. Scientific American. Retrieved, May 18, 2013 from http://www.scientificamerican.com/article.cfm?id=india-court-ruling-upholds-accessto-cheaper-generic-drugs.

Pascale, C. M. (2007). Making Sense of Race, Class, and Gender: Commonsense, Power, and Privilege in the United States. New York \& London: Routledge, Taylor \& Francis Group.

Rasmussen, B. B., Klinenberg, E., Nexica, I. J., \& Wray, M. (2004 (eds.). The making and unmaking of whiteness (pp. 1-24). Durham, NC: Duke University Press.

Sefa-Dei, G. J. (1996). Critical perspectives in antiracism: An introduction. The Canadian Review of Sociology and Anthropology, 33(3), 247-268.

Seidman, I. E. (1991). Interviewing as qualitative research: A guide for researchers in education and social sciences. Thousand Oaks, CA: Teachers College Press.

Shome, R. (1999). Whiteness and the politics of location: Postcolonial reflections. In T. K. Nakayama \& R. L. Krizek (Eds.), Whiteness: The communication of social identity (pp. 107-128). Thousand Oaks, CA: Sage.

Steyn, M. (2001). "Whiteness just isn't what it used to be." New York: State University of New York Press.

Sullivan, S. (2006). Revealing Whiteness: The Unconscious Habits of Racial Privilege. Bloomington and Indianapolis: Indiana University Press.

Wander, P. C., Martin, J. N., \& Nakayama, T. K. (1999). Whiteness and beyond: Socio-historical foundations of whiteness and contemporary challenges. In T. K. Nakayama \& J. N. Martin (Eds.), Whiteness: The communication of social identity (pp. 13-26). Thousand Oaks, CA: Sage.

Warren, J.W., and Twine, France. W. (1997). "White Americans, the New Minority? NonBlacks and the Ever-Expanding Boundaries of Whiteness." Journal of Black Studies 28:200-218.

Yale Daily News (2013, February 25). NEWS' VIEW: A long-term approach to faculty diversity. Retrieved, April 23, 2013 from:

http://yaledailynews.com/blog/2013/02/25/news-view-a-long-term-approach-to-faculty-diversity/

Yankah, K. (Spring, 1999). African Folk and the Challenges of a Global Lore. African Today 46(2): 9-27. 
